\title{
Studies on Correlation and Path Coefficient Analysis for Quantitative Traits in Blackgram (Vigna mungo L. Hepper)
}

\author{
Aman Mishra* and G. R. Lavanya \\ Department of Genetics and Plant Breeding, Sam Higginbottom University of Agriculture \\ Technology \& Sciences, Prayagraj, Uttar Pradesh, India \\ *Corresponding author
}

\section{A B S T R A C T}

\section{Keywords}

Blackgram, GCV, PCV, Heritability, Genetic advance, Correlation and Path Coefficient Analysis

\section{Article Info}

Accepted: 04 December 2020 Available Online: 10 January 2021
The present investigation was carried out with 22 genotypes during zaid2019 at Experimentation Centre, Department of Genetics and Plant Breeding, Naini Agricultural Institute, Sam Higginbottom University of Agriculture Technology and Science, Prayagraj. The genotypes were planted in Randomized Block Design with three replications with an aim to determine genetic variability, correlation, direct and indirect relationship between yield and its component characters. Mean squares due to genotypes for all the characters were highly significant as revealed from ANOVA indicating substantial amount of genetic variability among the genotypes under study. Mean performance results have shown that genotypes KU-719, KU88-9-1, Shekhar-1 followed by Azad-1 showed better performance for seed yield. Moderate to high GCV, PCV and heritability is coupled with high genetic advance as per cent of mean were being observed for plant height, number of clusters per plant, number of pods per plant, harvest index, seed index and seed yield per plant. Seed yield is significantly and positively correlated with number of clusters per plant, number of pods per plant and harvest index at phenotypic level. Path coefficient analysis revealed that maximum positive direct effect on seed yield per plant was exhibited by number of pods per plant followed by harvest index. Therefore simultaneous selection for pods per plant, harvest index and number of clusters per plant is suggested for improvement of grain yield per plant in blackgram.

\section{Introduction}

Blackgram (Vigna mungo L. Hepper) is commonly known as urd, mesh or kalidaal. India is the primary center of origin of Blackgram and Central Asia is the secondary center of origin. It is one of the most important legumes of India which belongs to family fabaceae or leguminoceae, sub-order paplionaceae and the tribe phaseolae with chromosome number $(2 n=2 x=22)$. It is annual crop, erect or sub-erect plant having trifoliate with paplionaceous flowers. Blackgram is one of the most important pulse crops of India cultivated over a wide range of agro-climatic situations. The major blackgram growing states of the country are Maharashtra, Andhra Pradesh, Madhya Pradesh, Uttar Pradesh, Tamil Nadu, Karnataka and Rajasthan. Being short duration and photo, thermo-insensitive, 
blackgram is considered as excellent for crop intensification and diversification. Development of short duration, photo, thermo-insensitive and disease resistant varieties has led to its cultivation as a sole or intercrop during spring season in North India and as a sole relay crop in rabi season in the rice fallows of the coastal peninsula.

India is world's largest producer as well as consumer of Blackgram. It produces about 3.06 milliontonnes of Blackgram annually from about 4.49 million hectares of area with an average productivity of $681.51 \mathrm{~kg}$ per hectare (Directorate of Economics and Statistics, Ministry of Agriculture and Farmers Welfare 2018-19). Blackgram is a rich source of quality protein $(24 \%)$ to the predominantly vegetarian population of the Indian subcontinent. Besides proteins, it is also rich in carbohydrates (59.69-63\%), dietary fibers $(16 \%)$, minerals $(3.2 \%)$ and fats $(1.4-1.6 \%)$. It is also a rich source of calcium (154mg/100gm), phosphorus (385mg/100gm) and iron $(9.1 \mathrm{mg} / 100 \mathrm{gm})$. It is also the richest source of phosphoric acid among pulses (5$6 \%$ richer than others). The calorific value of blackgram is $347 \mathrm{kcal} / 100 \mathrm{gm}$ and its moisture percentage is $10-11 \%$.

The per capita availability of pulses has declined from $60.7 \mathrm{gm} /$ day in 1951 to $35.5 \mathrm{gm} /$ day in 2007 as against the $\mathrm{FAO} / \mathrm{WHO}$ 's recommendation of $80 \mathrm{gm} /$ day (Economic Survey, 2008-09). In this regard the production potential of blackgram crop can be enhanced by developing high yielding genotypes through planned hybridization programmes.

Seed yield being a complex character is influenced by several genetic factors interacting with environment. A clear understanding of the association of plant characters with yield is necessary for successful crop improvement programme.
Correlation coefficient reveals magnitude and direction of association of yield components. Correlation coefficient analysis measures the mutual relationships between various plant character pairs and determines the component characters on which selection can be based for improvement in yield. Character association helps in formulating an effective breeding strategy to develop productive genotypes.

\section{Materials and Methods}

The germplasm collection of 22 varieties/strains of blackgram (Vigna mungo L. Hepper) constituted the experimental material for the study. These genotypes exhibiting wide spectrum of variability for various agronomic and morphological characters were obtained from the pulse section, Department of Genetics and Plant Breeding, Sam Higginbottom Institute of Agriculture Technology and Sciences, Prayagraj, 211007. The present experiment was carried out in Zaid 2019 in Randomised Block Design. The treatments were being replicated three times. The net area was around $111 \mathrm{~m}^{2}$ with a plot size of $1 * 1 \mathrm{~m}^{2}$ the row to row spacing $30 \mathrm{~cm}$ and plant to plant distance $10 \mathrm{~cm}$. Soil in this region is sandy loam and alkaline in nature. The technique of random sampling was adopted for the observation of the 12 quantitative characters namely days to 50 percent flowering, plant height, number of primary branches per plant, number of secondary branches per plant, number of pods per plant, pod length, number of seeds per pod, days to maturity, biological yield per plant, 100 seed weight, harvest index and seed yield per plant. Recommended practices were applied to raise a healthy crop. Metric data on 12 quantitative characters were taken at different stages of growth.

The experimental data thus recorded on these characters were subjected to statistical and biometrical analysis for Analysis of variance 
(Fisher, 1936), different genetic parameters Coefficient of variation (GCV, PCV) (Burton, 1952), estimation of heritability (Burton and De Vane, 1953), genetic advance (Johnson, et al., 1995), correlation coefficient analysis (Al-Jibouri, et al., 1958) and path analysis (Dewey and Lu, 1959).

Correlation coefficient estimates degree of association of different component characters of yield among themselves and with the yield. The correlation studies between various yields attribute with yield provides a basis for further breeding programme. Path coefficient analysis measures the direct effect of variable upon another and permits the separation of the correlation coefficient into components of direct and indirect effects. Information on the variability and correlation studies among the economic characters of the crop is of great value to plant breeders. It will not only, help to understand the desirable and undesirable relationship of economic characters but also help in assessing the scope of simultaneous improvement of two or more attributes.

\section{Results and Discussion}

\section{Genetic variability}

High genotypic coefficient of variation was observed in harvest index (40.44), number of pods per plant (29.09) and seed yield per plant (25.76). Moderate genotypic coefficient of variation was observed in seed index (17.67), number of clusters per plant (16.00), plant height (14.45) and biological yield (12.13). Low genotypic coefficient of variation was observed in number of seeds per pod (4.75), pod length (4.65), days to $50 \%$ flowering (4.19), number of primary branches per plant (4.11) and days to maturity (1.39). High phenotypic coefficient of variation was observed in harvest index (53.03), number of pods per plant (40.03), seed yield per plant (38.11), biological yield (35.83) and number of clusters per plant (25.92). Moderate phenotypic coefficient of variation was observed in plant height (19.62) and seed index (17.77) (Table 1 and 2).

Table.1 Analysis of variance for 12 characters in blackgram

\begin{tabular}{|l|l|c|c|c|}
\hline S.No. & Characters & Replication & Treatment & Error \\
\cline { 3 - 4 } & & {$[2]$} & {$[21]$} & {$[42]$} \\
\hline 1. & Days to 50\% flowering & 13.68 & $11.76^{* *}$ & 3.95 \\
\hline 2. & Days to maturity & 1.22 & $3.12^{* *}$ & 0.25 \\
\hline 3. & Plant height (cm) & 382.17 & $91.56^{* *}$ & 20.07 \\
\hline 4. & $\begin{array}{l}\text { Number of primary branches per } \\
\text { plant }\end{array}$ & 0.0018 & $0.0097 *$ & 0.0043 \\
\hline 5. & Number of clusters per plant & 3.53 & $5.24 * *$ & 1.84 \\
\hline 6. & Number of pods per plant & 274.63 & $123.69 * *$ & 28.37 \\
\hline 7. & Pod length (cm) & 0.01 & $0.13 * *$ & 0.02 \\
\hline 8. & Number of seeds per pod & 0.03 & $0.45 * *$ & 0.19 \\
\hline 9. & Biological yield (g) & 4384.24 & $1198.03 * *$ & 862.83 \\
\hline $\mathbf{1 0 .}$ & Harvest index (\%) & 152.68 & $306.09 * *$ & 59.22 \\
\hline 11. & Seed index (g) & 0.0013 & $1.51 * *$ & 0.0053 \\
\hline 12. & Seed yield per plant $(\mathrm{g})$ & 280.01 & $85.58^{* *}$ & 24.28 \\
\hline
\end{tabular}

$* 5 \%$ level of significance, $* * 1 \%$ level of significance

[ ] degree of freedom 
Table. 2 Genetic parameters for 12 characters in blackgram

\begin{tabular}{|c|c|c|c|c|c|c|c|c|}
\hline S.No. & Character & $\begin{array}{c}\text { Genotypic } \\
\text { Variance } \\
\left(V_{\mathrm{g}}\right)\end{array}$ & $\begin{array}{c}\text { Phenotypic } \\
\text { Variance } \\
\left(\mathbf{V}_{\mathbf{p}}\right)\end{array}$ & $\begin{array}{c}\text { Genotypic } \\
\text { Coefficient } \\
\text { of Variation } \\
(\%)\end{array}$ & $\begin{array}{c}\text { Phenotypic } \\
\text { Coefficient of } \\
\text { Variation } \\
(\%)\end{array}$ & $\begin{array}{c}\text { Heritability } \\
\left(\mathbf{h}^{2}\right)(\%) \\
\text { (broad sense) }\end{array}$ & $\begin{array}{c}\text { Genetic } \\
\text { advance } \\
(5 \% \\
\text { LOS })\end{array}$ & $\begin{array}{c}\text { Genetic } \\
\text { advance as per } \\
\text { cent of mean }\end{array}$ \\
\hline 1. & Days to $50 \%$ flowering & 2.60 & 6.55 & 4.19 & 6.65 & 39.7 & 2.09 & 5.44 \\
\hline 2. & Days to maturity & 0.95 & 1.12 & 1.39 & 1.57 & 78.6 & 1.78 & 2.55 \\
\hline 3. & Plant height & 23.83 & 43.90 & 14.45 & 19.62 & 54.3 & 7.40 & 21.94 \\
\hline 4. & Primary branches per plant & 0.002 & 0.006 & 4.11 & 7.63 & 29.1 & 0.04 & 4.57 \\
\hline 5. & Clusters per plant & 1.13 & 2.97 & 16.00 & 25.92 & 38.1 & 1.35 & 20.35 \\
\hline 6. & Pods per plant & 31.77 & 60.14 & 29.09 & 40.03 & 52.8 & 8.43 & 43.56 \\
\hline 7. & Pod length & 0.03 & 0.06 & 4.65 & 5.98 & 60.5 & 0.30 & 7.46 \\
\hline 8. & Seeds per pod & 0.08 & 0.28 & 4.75 & 8.63 & 30.3 & 0.33 & 5.38 \\
\hline 9. & Biological yield & 111.73 & 974.56 & 12.13 & 35.83 & 11.5 & 7.37 & 8.46 \\
\hline 10. & Harvest index & 82.28 & 141.51 & 40.44 & 53.03 & 58.1 & 14.25 & 63.53 \\
\hline 11. & Seed index & 0.50 & 0.50 & 17.67 & 17.77 & 99.0 & 1.45 & 36.22 \\
\hline 12. & Seed yield per plant & 20.43 & 44.71 & 25.76 & 38.11 & 45.7 & 6.29 & 35.87 \\
\hline
\end{tabular}


Table.3 Correlation coefficient between yield and its component characters in blackgram at phenotypic level

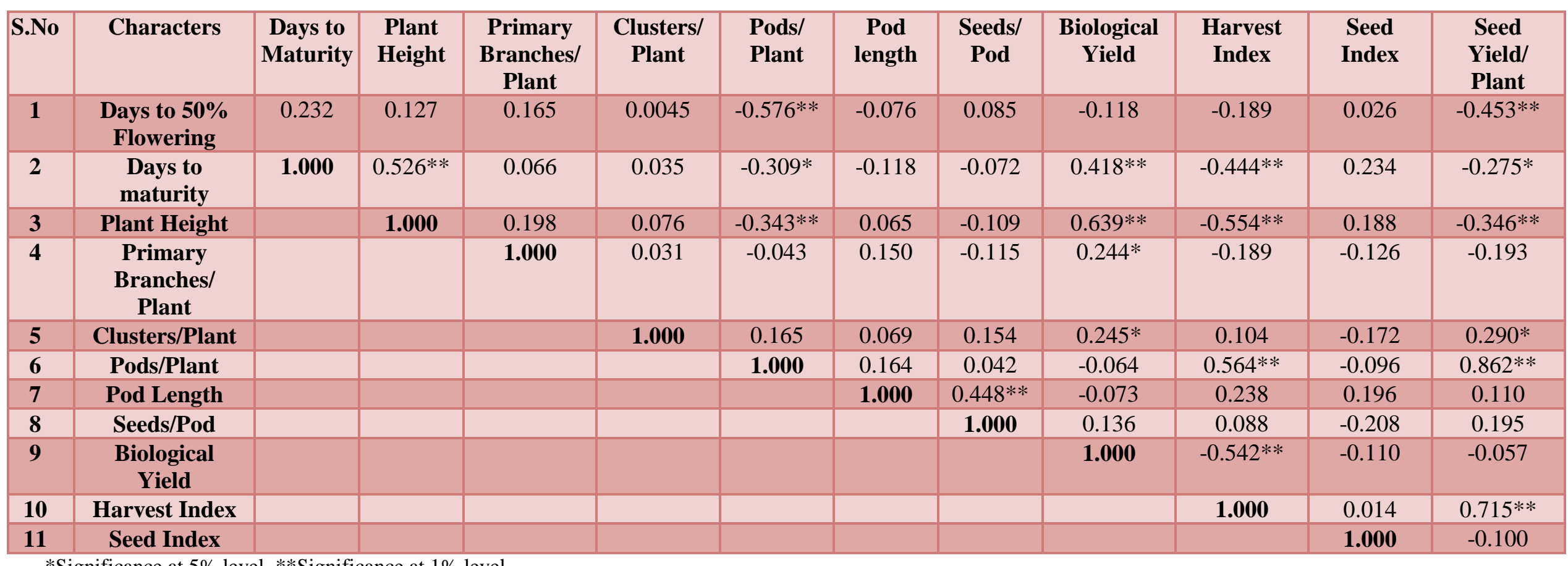

*Significance at $5 \%$ level, **Significance at $1 \%$ level 
Table.4 Direct (diagonal) and indirect effects of different correlated characters towards seed yield per plant

\begin{tabular}{|c|c|c|c|c|c|c|c|c|c|c|c|c|}
\hline Character & $\begin{array}{c}\text { Days to } \\
50 \% \\
\text { flowering }\end{array}$ & $\begin{array}{l}\text { Days to } \\
\text { Maturity }\end{array}$ & $\begin{array}{c}\text { Plant } \\
\text { Height }\end{array}$ & $\begin{array}{c}\text { Primary } \\
\text { Branches/ } \\
\text { Plant }\end{array}$ & $\begin{array}{c}\text { Clusters } \\
/ \\
\text { Plant } \\
\end{array}$ & $\begin{array}{l}\text { Pods/ } \\
\text { Plant }\end{array}$ & $\begin{array}{c}\text { Pod } \\
\text { Length }\end{array}$ & $\begin{array}{l}\text { Seeds/ } \\
\text { Pod }\end{array}$ & $\begin{array}{l}\text { Biological } \\
\text { Yield }\end{array}$ & $\begin{array}{l}\text { Harvest } \\
\text { Index }\end{array}$ & $\begin{array}{l}\text { Seed } \\
\text { Index }\end{array}$ & $\begin{array}{c}\text { Seed Yield/ } \\
\text { Plant }\left(\mathbf{R}_{\mathbf{p}}\right)\end{array}$ \\
\hline $\begin{array}{c}\text { Days to } \\
50 \% \\
\text { flowering }\end{array}$ & -0.013 & -0.003 & -0.001 & -0.002 & -0.0001 & 0.007 & 0.001 & -0.001 & 0.001 & 0.002 & 0.0003 & $-0.453 * *$ \\
\hline $\begin{array}{l}\text { Days to } \\
\text { Maturity }\end{array}$ & 0.006 & 0.029 & 0.015 & 0.001 & 0.001 & -0.009 & -0.003 & -0.002 & 0.012 & -0.013 & 0.006 & $-0.275^{*}$ \\
\hline $\begin{array}{l}\text { Plant } \\
\text { Height }\end{array}$ & 0.006 & 0.028 & 0.054 & 0.010 & 0.004 & -0.018 & 0.003 & -0.006 & 0.034 & -0.030 & 0.010 & $-0.346 * *$ \\
\hline $\begin{array}{c}\text { Primary } \\
\text { Branches/ } \\
\text { Plant }\end{array}$ & -0.012 & -0.005 & -0.015 & -0.075 & -0.002 & 0.003 & -0.011 & 0.008 & -0.018 & 0.014 & 0.009 & -0.193 \\
\hline $\begin{array}{c}\text { Clusters / } \\
\text { Plant }\end{array}$ & 0.0004 & 0.002 & 0.006 & 0.002 & 0.080 & 0.013 & 0.005 & 0.012 & 0.019 & 0.008 & -0.013 & $0.290 *$ \\
\hline $\begin{array}{l}\text { Pods/ } \\
\text { Plant }\end{array}$ & -0.355 & -0.190 & -0.211 & -0.026 & 0.102 & 0.616 & 0.101 & 0.026 & -0.04 & 0.348 & -0.059 & $0.862 * *$ \\
\hline $\begin{array}{c}\text { Pod } \\
\text { Length }\end{array}$ & 0.013 & 0.021 & -0.011 & -0.026 & -0.012 & -0.029 & -0.177 & -0.079 & 0.013 & -0.042 & -0.034 & 0.110 \\
\hline Seeds/Pod & 0.015 & -0.012 & -0.019 & -0.020 & 0.026 & 0.007 & 0.078 & 0.174 & 0.023 & 0.015 & -0.036 & 0.195 \\
\hline $\begin{array}{c}\text { Biological } \\
\text { Yield }\end{array}$ & -0.020 & 0.072 & 0.110 & 0.042 & 0.042 & -0.011 & -0.012 & 0.023 & 0.173 & -0.093 & -0.019 & -0.057 \\
\hline $\begin{array}{c}\text { Harvest } \\
\text { Index }\end{array}$ & -0.095 & -0.224 & -0.280 & -0.095 & 0.052 & 0.285 & 0.120 & 0.044 & -0.274 & 0.505 & 0.007 & $0.715 * *$ \\
\hline $\begin{array}{l}\text { Seed } \\
\text { Index }\end{array}$ & 0.0008 & 0.007 & 0.005 & -0.003 & -0.005 & -0.002 & 0.005 & -0.006 & -0.003 & 0.0004 & 0.029 & -0.100 \\
\hline
\end{tabular}


Fig.1 Phenotypic path diagram in blackgram

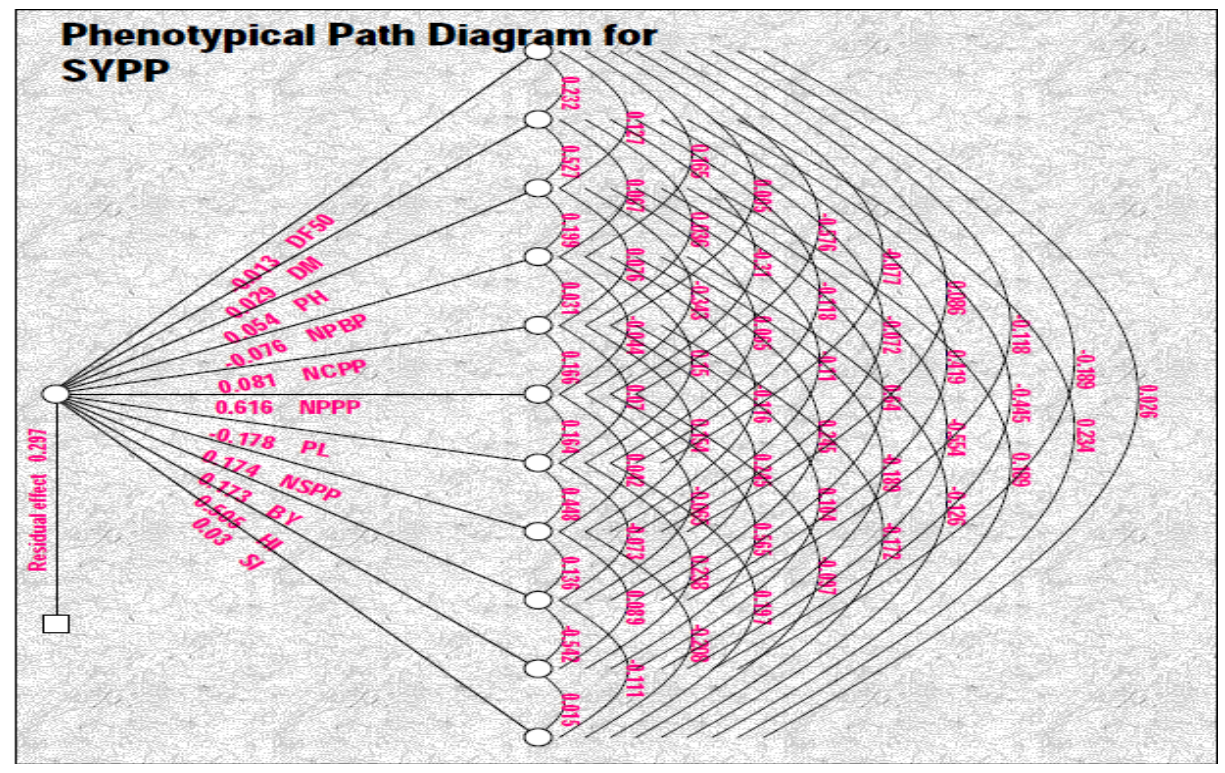

Low phenotypic coefficient of variation was observed in number of seeds per pod (8.63), number of primary branches per plant (7.63), days to $50 \%$ flowering (6.65), pod length (5.98) and days to maturity (1.57). High heritability was observed in seed index (99.0), days to maturity (78.6) and pod length (60.5). Moderate heritability was observed in harvest index (58.1), plant height (54.3), number of pods per plant (52.8), seed yield per plant (45.7), days to $50 \%$ flowering (39.7), number of clusters per plant (38.1) and number of seeds per pod (30.3). Low heritability was observed in number of primary branches per plant (29.1) and biological yield (11.5). Genetic advance was observed harvest index (14.25), number of pods per plant (8.43), plant height (7.40), biological yield (7.37), seed yield per plant (6.29), days to $50 \%$ flowering (2.09), days to maturity (1.78), seed index (1.45), number of clusters per plant (1.35), number of seeds per pod (0.33), pod length $(0.30)$ and primary branches per plant (0.04). High genetic advance as per cent of mean was observed in harvest index (63.53), number of pods per plant (43.56), seed index
(36.22) and seed yield per plant (35.87), plant height (21.94) and number of clusters per plant (20.35). Low genetic advance as per cent of mean was observed in biological yield (8.46), pod length (7.46), days to 50\% flowering (5.44), seeds per pod (5.38), number of primary branches per plant (4.57) and days to maturity (2.55) (Fig. 1).

Johnson et al., (1955) and Panse (1967) suggested high estimates of heritability and genetic advance as per cent of mean should be taken into consideration for selection for base improvement. Heritability alone provides no identification of the amount if genetic improvement that would result from selection of individual genotypes.

The estimates of variability parameters revealed that phenotypic coefficient of variation along with least difference from genotypic coefficient of variation were observed for the characters viz., seed index (PCV 17.77\% and GCV 17.67\%) followed by days to maturity (PCV $1.57 \%$ and GCV $1.39 \%$ ), pod length (PCV 5.98\% and GCV 
$4.65 \%$ ) and days to $50 \%$ flowering (PCV $6.65 \%$ and GCV $4.19 \%$ ) indicating the greater role of genetic factors influencing the expression of these characters. These characters also showed high to moderate heritability. Thus, it indicated the utility of these characters in the selection programme.

\section{Correlation coefficient analysis}

In table 3 the present study in phenotypic correlation the seed yield per plant was found to be highly significant and in positive correlation with pods per plant, harvest index and clusters per plant. Pod length and seeds per pod having the positive and nonsignificant relationship with the seed yield per plant.

\section{Path coefficient analysis}

In table 4 the highest positive direct effect on seed yield per plant was exhibited by number of pods per plant (0.616) followed by harvest index (0.505) and low positive direct effect was exhibited by number of clusters per plant (0.080). While, high indirect effects on seed yield per plant was exhibited positive and negative through other character.

The result from the present experiment concluded that all the 22 genotypes of blackgram showed significant differences for all the characters. Mean performance results have shown that genotypes KU-719, KU88-91, Shekhar-1 and Azad-1 showed better performance for seed yield. Plant height, number of clusters per plant, number of pods per plant, harvest index, seed index and seed yield per plant exhibited moderate to high GCV, PCV and heritability is coupled with high genetic advance as percent of mean. Correlation and path coefficient analysis revealed that number of pods per plant, harvest index followed by clusters per plant has significant positive association on seed yield and they also exhibit high positive direct effect on seed yield. All four genotypes mentioned above with these characters can be used for further improvement and development of blackgram.

\section{References}

Al-jibouri, H. A., Miller, P. A. and Robinson, H. F. (1958). Genetic and environmental variance and covariance in an upland cotton cross of the inter specific origin. Agronomy Journal, 50(2): 633-636.

Ali, M.N., Gupta, S., Bhattacharya, S. and Sarkar, H.K. (2008). Character association of urdbean. Environment and Ecology, 26: 952-954.

Babu, A., Kamala, V., Sivaraj, N., Pandravada, S.R., Vanaja and Varaprasad, K.S. (2010). DIVA-GIS approaches for diversity assessment of pods characteristics in blackgram (Vigna mungo L. Hepper). Current SciencesI. 98: 616:619.

Babu, J.S., Reni, Y.P. and Ramana, M.V. (2016). Character association and path coefficient in blackgram (Vigna mungo L. Hepper). International Research of Natural and Applied Sciences, 3: 178-185.

Burton, G. W. (1952). Quantitative inheritance in grasses. Proc. 6th International Grassland Cong. 1(1): 277-283.

Burton, G. W. and Devane (1953). Estimating heritability in tall feeseue from replicated clonal material. Journal of Agronomy, 45(7): 474-481.

Dewey, D.R. and Lu, K.H. (1959). A correlation and path analysis of components of crested wheat grass seed production. Agronomy Journal.51(2): 515-518.

Directorate of economics and statistics, 2019: The annual report on crop production, 
published by ministry of agriculture and farmers welfare.

Fisher, R.A. and Yates, F. (1963). Statistical Tables for Biological, Agricultural and Medical Research. 6th edn., Oliver and Boyd Ltd., Edinburg.

Hadimani, A., Konda, C.R. and Kulkarni, V. (2019). Correlation and path coefficient analysis for yield and yield components in blackgram (Vigna mungo L. Hepper). International Journal of Chemical Studies, 7(1): 2240-2243.

Hanson, C.H., Robinson, H.F., Comstock, R.E. (1956). The biometrical studies on yield in segregating population of Korean lespedeza. Agronomy Journal, 48: 268-272.

Gowsalya, P., Kumaresan, D. Packiaraj, D. and Babu, K.J.R. (2016). Genetic variability and character association for biometrical traits in blackgram (Vigna mungo 1. Hepper). Electronic Journal of Plant Breeding. 7(2):317324.

Johnson, H.W., Robinson, H.F. and Comstock, R.E. (1955). genotypic and phenotypic correlation in soyabean and their implication in selection. Agronomy Journal, 47:438-477.

Jyotsana, S., Patro, T.S.S.K., Ashok, S. SandhyaY., Rani and Neeraja, B (2016). Character association and path analysis of seed yield and its yield components in Blackgram (Vigna mungo (L.) Hepper). International Journal of Theoretical and Applied Sciences, 8(1):12-16.

Kumar, G.V., Vanaja, M., Sathish, P., Vagheera, P. and Lakshmi (2015). Correlation analysis for quantitative traits in blackgram (Vigna mungo (L.) Hepper). International Journal of Scientific and Research Publications. 5(4):1-4.

Konda, C.R., Salimath, P.M. and Mishra,
M.N. (2008). Correlation and path analysis in blackgram (Vigna mungo L. Hepper). Legume Research, 32: 202-205.

Lush (1949). Inter-se correlation and regression of characters. Proceeding to American Society of Animal Production. 33:293-301.

Panigrahi, K.K., and Baisakh, B. (2014). Correlation and path coefficient analysis for quantitative traits in balckgram (Vigna mungo L. Hepper) in different seasons. International Journal of Scientific and Research Publications, 5, Issue 4.

Panse, V.G. (1957). Genetics of quantitative characters in relation to plant breeding. Indian Journal of Genetics and Plant Breeding, 17:318-328.

Panse, V.G. and Sukhatme, P.V. (1978). Statistical Methods for Agricultural Workers. Indian Council of Agricultural Research, New Delhi, $3^{\text {rd }}$ ed.

Parveen, S.I., Sekhar, M.R., Reddy, D.M. and Sudhakar, P. (2011). Correlation and path coefficient analysis for yield and yield components in blackgram (Vigna mungo (L.) Hepper). International Journal of Applied Biology and Pharmaceutical Technology, 2(3):619625.

Rao, C.R. (1952). The utilization of multiple measurements in problems of biological classification. Journal of Royal Statistics Society, 10:159-203.

Rolaniya, D.K., Jinjwadiya, M.K., Meghwal, D.R. and Lal, G.M. (2017). Studies on genetic variability in Blackgram (Vigna mungo L. Hepper) germplasm. Journal of Pharmacognosy and Phytochemistry, 6(4): 1506-1508.

Senthamizhselvi, S., Muthuswamy, A. and Shunmugavalli, N. (2019). Genetic variability, correlation and path coefficient analysis for yield and yield 
components in blackgram. Electronic Journal of Plant Breeding, 10(4): 1600-1605.

Shalini, C.H. and Lal, G.M. (2019) correlation and path coefficient analysis for yield and yield components in blackgram (Vigna mungo L. Hepper). The Pharma Innovation Journal, 8(6): 65-68.

Tank, H.K. and Sharma, P.P. (2019). Correlation and path coefficient analysis in blackgram (Vigna mungo (L.) Hepper). Electronic Journal of Plant Breeding, 10(3): 1333-1338.

Vavilov, N. I. (1926). Studies on the origins of cultivated plants. Bullet Applied
Plant Breeding, 16(1): 245.

Whyte, R.O., Nilsson-Leissner, G and Trumble, H.C. (1953). Legumes in Agriculture. FAO Agriculture Studies, 21: 262.

Wilkis, S.S. (1932). Certain generalizations in the analysis of variance. Biometrics, 24: 471 .

Wright, S. (1921). Correlation and causation. Journal of Agricultural Research, 20: 557-558.

Zukovskiji, P.M. (1962). Cultivated plants and their wild relatives, Commonwealth Agriculture Bureau, London.

\section{How to cite this article:}

Aman Mishra and Lavanya, G. R. 2021. Studies on Correlation and Path Coefficient Analysis for Quantitative Traits in Blackgram (Vigna mungo L. Hepper). Int.J.Curr.Microbiol.App.Sci. 10(01): 372-381. doi: https://doi.org/10.20546/ijcmas.2021.1001.046 